\title{
Male genital tract immune response against Chlamydia trachomatis infection
}

\author{
Juan Pablo Mackern-Oberti, ${ }^{1,2}$, Rubén Darío Motrich ${ }^{3}$, Maria Teresa Damiani ${ }^{4}$, \\ Héctor Alex Saka ${ }^{3}$, Cristian Andrés Quintero ${ }^{5}$, Leonardo Rodolfo Sánchez ${ }^{3}$, \\ Tamara Moreno-Sosa ${ }^{1}$, Carolina Olivera ${ }^{3}$, Cecilia Cuffini ${ }^{6}$ and Virginia Elena Rivero ${ }^{3}$ \\ 'Instituto de Medicina y Biología Experimental de Cuyo. IMBECU-CONICET, Mendoza, Argentina, ${ }^{2}$ Instituto de \\ Fisiología. Facultad de Ciencias Médicas, Universidad Nacional de Cuyo, Mendoza, Argentina, ${ }^{3}$ Centro de \\ Investigaciones en Bioquímica Clínica e Inmunología CIBICI-CONICET, Departamento de Bioquímica Clínica, \\ Facultad de Ciencias Químicas, Universidad Nacional de Córdoba, Córdoba, Argentina, ${ }^{4}$ Instituto de Histología y \\ Embriología de Mendoza. IHEM-CONICET, Facultad de Ciencias Médicas, Universidad Nacional de Cuyo, \\ Mendoza, Argentina, ${ }^{5}$ Facultad de Farmacia y Bioquímica, Universidad Juan Agustín Maza, Mendoza, Argentina \\ and ${ }^{6}$ Instituto de Virología Dr. J. M. Vanella, Facultad de Ciencias Médicas, Universidad Nacional de Córdoba, \\ Córdoba, Argentina
}

Correspondence should be addressed to V E Rivero or J P Mackern-Oberti; Email: vrivero@fcq.unc.edu.ar or jpmackern@ mendoza-conicet.gob.ar

\begin{abstract}
Chlamydia trachomatis is the most commonly reported agent of sexually transmitted bacterial infections worldwide. This pathogen frequently leads to persistent, long-term, subclinical infections, which in turn may cause severe pathology in susceptible hosts. This is in part due to the strategies that Chlamydia trachomatis uses to survive within epithelial cells and to evade the host immune response, such as subverting intracellular trafficking, interfering signaling pathways and preventing apoptosis. Innate immune receptors such as toll-like receptors expressed on epithelial and immune cells in the genital tract mediate the recognition of chlamydial molecular patterns. After bacterial recognition, a subset of pro-inflammatory cytokines and chemokines are continuously released by epithelial cells. The innate immune response is followed by the initiation of the adaptive response against Chlamydia trachomatis, which in turn may result in T helper 1-mediated protection or in T helper 2-mediated immunopathology. Understanding the molecular mechanisms developed by Chlamydia trachomatis to avoid killing and host immune response would be crucial for designing new therapeutic approaches and developing protective vaccines. In this review, we focus on chlamydial survival strategies and the elicited immune responses in male genital tract infections.

Reproduction (2017) 154 R99-R110
\end{abstract}

\section{Chlamydia trachomatis and genital tract infections}

Chlamydia trachomatis (CT) is the leading cause of sexually transmitted bacterial infections in both, developing and developed countries (Mylonas 2012, Gottlieb et al. 2013, WHO 2016). According to the World Health Organization, approximately 131 million new cases of chlamydial genital infections are diagnosed worldwide every year (WHO 2016).

CT infections mainly occur in young fertile women, who suffer from urethritis, cervicitis, endometritis, salpingitis to pelvic inflammatory disease (PID), ectopic pregnancy or tubal infertility (reviewed in (Haggerty et al. 2010, Kortekangas-Savolainen et al. 2012, Refaat et al. 2016). The most important feature of CT genital infections is their asymptomatic nature, leading to long-term subclinical infections responsible for permanent sequelae in the female genital apparatus (Gottlieb et al. 2010). In men, CT infects urethra being a major cause of male urethritis, which usually constitutes an acute episode of an underlying chronic silent infection affecting prostate, seminal vesicles, epididymis and testis (Furuya et al. 2005, 2009, Motrich et al. 2012, Mackern-Oberti et al. 2013).

In this review, we discuss the current knowledge regarding chlamydial recognition by epithelial cells and how these bacteria invade and survive within them. In addition, we review chlamydial strategies to evade host immune response to develop male genital tract infections. 


\section{Chlamydia trachomatis lifestyle}

\section{Attachment and invasion}

CT is a gram negative bacterium that displays an obligate intracellular lifestyle involving a unique biphasic cycle with two clearly defined developmental stages (de Jesus De Haro-Cruz et al. 2011, Elwell et al. 2016). Infection starts by the bacterial-driven endocytosis of the quiescent, environmentally resistant and highly infectious elementary body (EB). Several virulence factors have been linked to EBs attachment to epithelial cells such as a new adhesin and invasin protein from CT serovar E Ctad1 (CT017) (Stallmann \& Hegemann 2016), major outer membrane protein (MOMP) (Su et al. 1996), outer membrane complex protein B (OmcB)
(Fadel \& Eley 2007) and polymorphic membrane protein D (PmpD) (Wehrl et al. 2004).

Different host molecules have been associated to CT invasion such as heparan sulfate proteoglycans (HSPGs) (Kim et al. 2011), glycosaminoglycan (Menozzi et al. 2002), mannose receptor (CD206) (Kuo et al. 2002, Campbell et al. 2006), protein disulfide isomerase (PDI) (Conant \& Stephens 2007), platelet-derived growth factor receptor (PDGF-R), tyrosine kinase ephrinA2 receptor (EphA2) (Moorhead et al. 2010) and abelson kinase (Abl) (Elwell et al. 2008) (Fig. 1). Interestingly, EBs have the ability to directly bind to fibroblast growth factor 2 (FGF-2), which may enable their interaction with the FGF-2 receptor, triggering its activation that leads to the uptake of $\mathrm{CT}$ into

\section{Chlamydia trachomatis infection of an epithelial cell}

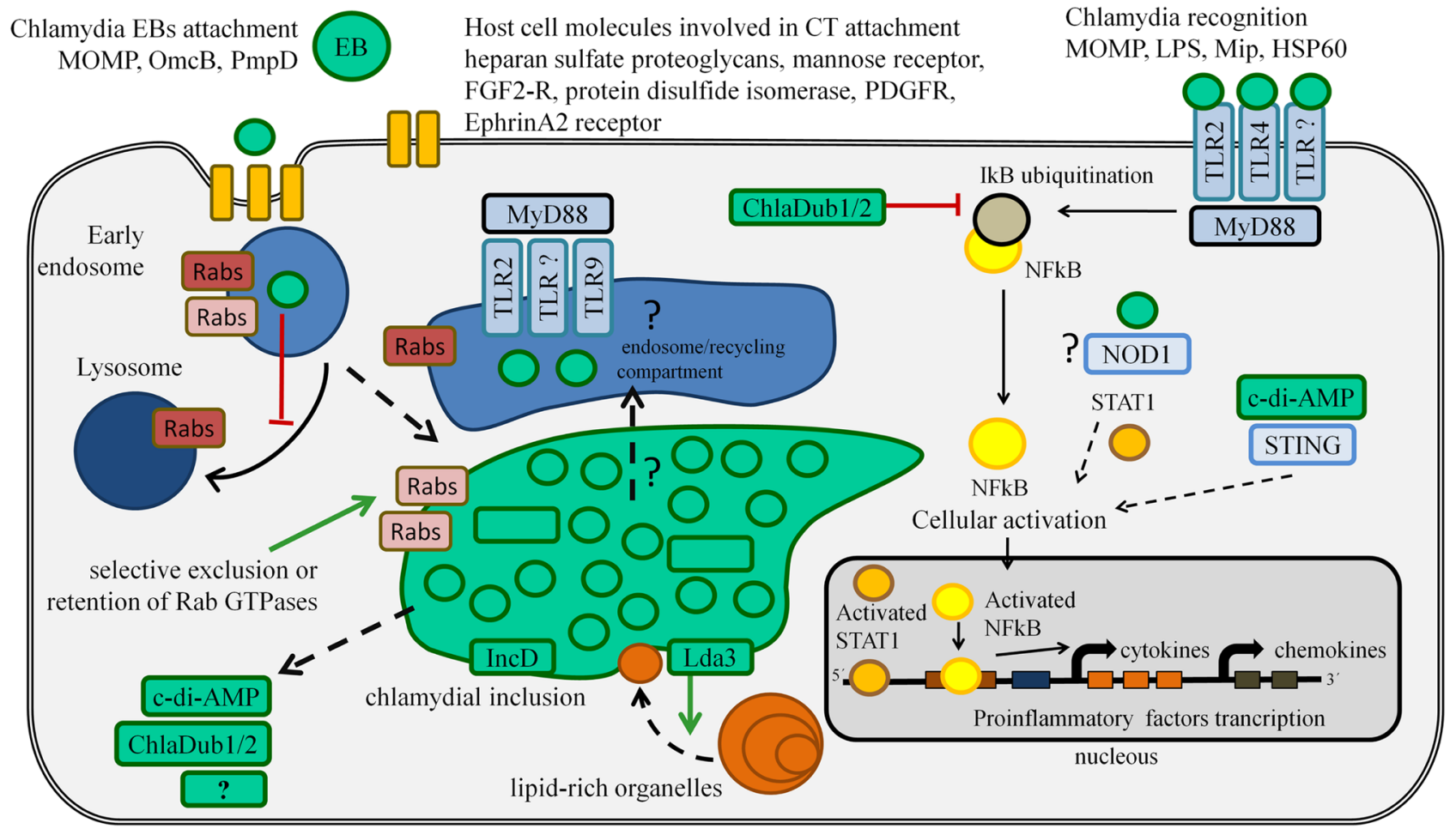

Figure 1 Chlamydia trachomatis infection of an epithelial cell. Several bacterial factors have been linked to EBs attachment to epithelial cells such as major outer membrane protein (MOMP), outer membrane complex protein B (OmcB) and polymorphic membrane protein subtype D (PmpD). On the other hand, several eukaryotic molecules are involved in CT binding to host cells such as heparan sulfate proteoglycans (HSPGs), mannose receptor (CD206), fibroblast growth factor 2 receptor (FGF2-R), protein disulfide isomerase (PDI), platelet derived growth factor receptor (PDGFR) and EphrinA2 receptor (EphA2). Host cells may recognize CT by different patterns recognition receptors (PRRs) such as toll-like receptor (TLRs), stimulator of interferon genes (STING) and nucleotide oligomerization domain 1 (NOD1). In turn, PRRs trigger nuclear factor kappa-light-chain-enhancer of activated B cells (NF-kB) activation, leading to Inhibitor of NF-kB (IkB) ubiquitination and NF-kB nuclear translocation. Chlamydial components such as ChlaDub1/2 (deubiquitinating enzymes) may interfere with this signaling pathway limiting apoptosis. Once inside the host cell, CT drives modifications of the Chlamydia-containing vacuole or 'inclusion' by the selective exclusion or retention of Rabs on the chlamydial inclusion membrane in order to manipulate host trafficking. In this way, CT avoids degradation by inhibiting fusion with lysosomes and redirects Golgi-derived vesicles and multivesicular bodies (MVBs) to the inclusion for the acquisition of sphingolipids and cholesterol. In addition, Chlamydia also recruits lipid-rich organelles from the host cytosol, such as lipid droplets, through chlamydial proteins like Lda3 (Lda are proteins secreted by chlamydia that bind to cytoplasmic lipid droplets, LDs). Green boxes indicate chlamydial molecules; green circles indicate EBs; green arrows indicate host proteins associated with chlamydia inclusion; black lines indicate intracellular pathways; red lines indicate signaling pathways modulated by chlamydia. Red blunt lines indicate inhibitory signals; green lines indicate activation signals; black lines indicate intracellular localization and traffic; and dotted black lines indicate theoretical mechanism. 
non-phagocytic cells (Kim et al. 2011). These data are summarized in Fig. 1.

Internalized EBs grow into a membrane-bound compartment known as the inclusion, in which they differentiate into larger, metabolically active and highly replicative reticulate bodies (RBs). After several rounds of replication, RBs are asynchronically turned back into EBs. At the end of the developmental cycle, which lasts $42-76 \mathrm{~h}$, the inclusion occupies most of the cell cytoplasm and contains these new EBs, which are released to the extracellular environment either by cellular lysis or extrusion. Consequently, infection is spread into neighboring cells (Valdivia 2008). Along the developmental cycle, chlamydial lipopolysaccharide (cLPS) and other chlamydial molecules including c-diAMP are sensed by host receptors such as toll-like receptor 4 (TLR4) and a cytosolic cyclic-nucleic acid-sensing protein named stimulator of interferon genes (STING) leading to NFKB and NLPR3-inflammasome activation (Barker et al. 2013, Finethy et al. 2015, Sixt et al. 2017, Webster et al. 2017). By these mechanisms, CT triggers host innate immune response and impairs mucosal homeostasis (Mackern-Oberti et al. 2011a, Barker et al. 2013). On the other hand, chlamydial plasmid is crucial for inducing immunopathology, which may be mediated by a toll-like receptor 2 (TLR2)-dependent mechanism. In agreement, plasmid-free CT or Chlamydia muridarum (CM) displayed an attenuated infection ( $\mathrm{O}^{\prime}$ Connell et al. 2007, 2011, Lei et al. 2014). Some Inc proteins such as incC, CT229, CT288, CT383 and CT449 are involved in bacterial replication contributing to inclusion membrane stability (Weber et al. 2017). Furthermore, these chlamydial proteins create a replicative niche that avoid innate immune recognition (Weber et al. 2017). A general view of bacterial and eukaryotic molecules involved in CT attachment to and invasion of host cells is shown in Fig. 1.

\section{Chlamydia trachomatis and host signaling}

CT has developed several molecular mechanisms to subvert or dampen the host immune response. Among them, CT prevents nuclear translocation of nuclear factor $\kappa \mathrm{B}(\mathrm{NF \kappa B})$ by the release of the chlamydial proteins ChlaDub1 and ChlaDub2 (deubiquitinating enzymes) that in turn interfere with inhibitor of NF-kB (lkB) ubiquitination (Misaghi et al. 2006) (Fig. 1). Additionally, CT exerts anti-apoptotic activity by triggering a pathway driven by mitogen-activated protein kinases, originally called extracellular signalregulated kinases (MAPK/ERK signaling) (Kun et al. 2013). Hence, CT ensures the survival of the infected cell. CT also modulates PLC 1 (phospholipase $C \gamma 1$ ) and Akt (protein kinase B) signaling pathways to promote chlamydial attachment, internalization and inclusion formation (Subbarayal et al. 2015). Indeed, upon chlamydial infection, there is a strong and sustained infection-mediated ERK activation, which in turn leads to upregulation of EphrinA2 receptor (Subbarayal et al. 2015). Although the mechanism is still unclear and controversial, the chlamydial secreted protease (CPAF) may also promote cell survival (Yang et al. 2016). In Fig. 1, we describe the main signaling pathways that are affected by chlamydial infection. Since most of them are also involved in the regulation of host immune response, it is likely that through common molecules, CT manipulates not only the intracellular environment of the infected cell but also overall host immunity.

\section{Chlamydia trachomatis controls intracellular transport}

CT has evolved highly specialized mechanisms to survive within human epithelial cells being able to scavenge nutrients from the host cell while being restricted into the inclusion (Saka \& Valdivia 2010).

CT drives modifications in host vesicular transport by selective exclusion or retention of Rab GTPases (family of small Ras-like GTPases) on the chlamydial inclusion membrane (Hackstadt 2012, Damiani et al. 2014). Rab5 and Rab7, which control transport in the phagocytic pathway, phagosome maturation and finally, the fusion with lysosomes, are conveniently excluded from the inclusion membrane (Rzomp et al. 2003, Hackstadt 2012). On the other hand, Rabs belonging to the endocytic recycling pathway like Rab4 and Rab11 are selectively retained on the chlamydial inclusion membrane. Furthermore, Rab6 and Rab14, GTPases that participate in intra-Golgi and post-Golgi transport, are recruited by CT to redirect endogenously synthesized host lipids (Rzomp et al. 2006, Rejman Lipinski et al. 2009, Capmany \& Damiani 2010). In addition, chlamydial inclusions interact with multivesicular bodies (MVBs, host organelles rich in cholesterol and sphingomyelin) through a Rab39amediated mechanism (Gambarte Tudela et al. 2015). Some Rab-interacting proteins have been found associated to chlamydial inclusions such as Rab6 effector Bicaudal D1, a dual Rab11- and Rab14-binding protein known as family of interacting protein 2 (FIP2), and the oculocerebrorenal syndrome of Lowe protein 1 (OCRL) that binds to multiple Rabs (some isoforms of Rab1, Rab3, Rab5, Rab6, Rab8, Rab13, Rab22 and Rab35) (Rzomp et al. 2006, Moorhead et al. 2007, 2010, Leiva et al. 2013) (Fig. 1).

Current evidence indicates that CT acquires lipids not only by hijacking Golgi-derived exocytic vesicles or multivesicular bodies (MVBs). Actually, CT has the ability to recruit lipid droplets (LDs, neutral lipid rich organelles) by the interaction with chlamydial protein Lda3 (Kumar et al. 2006, Cocchiaro et al. 2008). In agreement, in the absence of LDs, CT replication is significantly reduced (Saka et al. 2015). In fact, lipid droplet proteome in epithelial cells is modified in response to CT infection (Saka et al. 2015), (Fig. 1). 
Interestingly, CT also takes advantage of nonvesicular-mediated mechanisms for nutrient acquisition. Inclusion membrane protein IncD interacts with the endoplasmic reticulum (ER)-to-Golgi ceramide transfer protein CERT and the ER resident protein VAPB at ER-Chlamydia trachomatis inclusion membrane contact sites to acquire host sphingomyelin (Derre et al. 2011, Elwell et al. 2011). The main vesicular transport pathways and host lipid sources co-opted by CT are schematized in Fig. 1.

\section{Chlamydia trachomatis and persistent infections}

Interferon- $\gamma$ (IFN- $\gamma$ ) has an important role in the immune response to CT (Johansson et al. 1997, Perry et al. 1999, Gondek et al. 2009, Sherchand et al. 2016). The induction of indoleamine-2,3-dioxygenase 1 (IDO1) by this cytokine results in depletion of intracellular tryptophan, which in turn imposes nutritional stress to $\mathrm{CT}$, given that these bacteria are tryptophan auxotrophs (Byrne et al. 1986). In response to the nutritional stress, also caused by sphingolipids deprivation, CT enters into a low replicative viable state identified by the presence of persistent or aberrant bacterial forms, which are able to resume normal replication as soon as conditions are favorable again. Persistent bacteria are linked to infection chronification (Beatty et al. 1994a,b, Wyrick 2010).

In summary, current knowledge supports the concept that CT ensures its survival, development and replication by hijacking multiple vesicle pathways to seize host cells for its own benefit. These findings have been achieved by in vitro studies in epithelial cells. However, whether similar mechanisms occur inside infected immune cells such as dendritic cells (DCs) and macrophages affecting $\mathrm{T}$ cell priming remain elusive.

\section{Innate immune response against Chlamydia trachomatis}

\section{Epithelial cells as the first immune barrier}

Urethra or vagina/endocervix epithelia are physical barriers in which takes place the first contact between the host and CT. Male (MGT) and female genital tract (FGT) epithelial cells can recognize CT through pattern

Chlamydia trachomatis recognition by eptithelial Chlamydia HSPO0 $_{4}$ cells, monocytes and dendritic cells

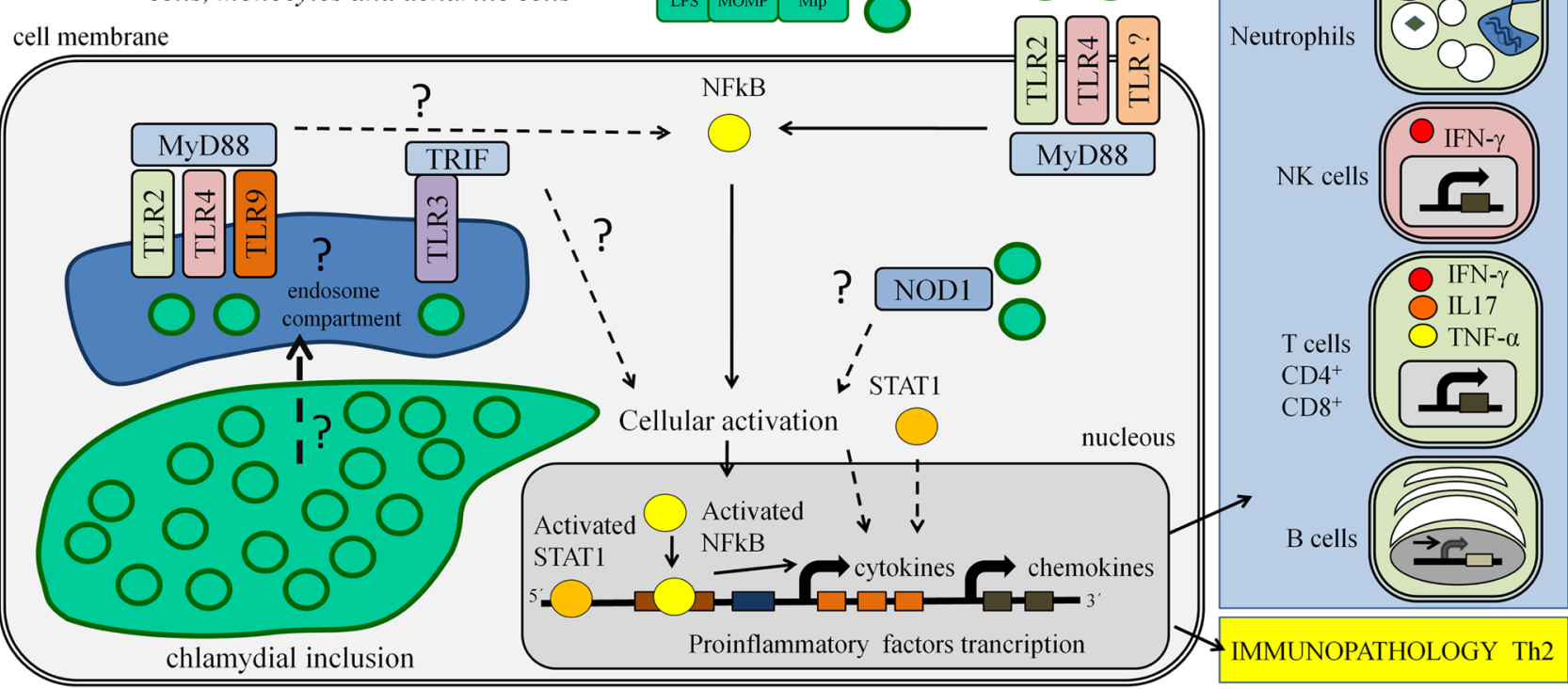

Figure 2 Proposed mechanisms by which CT is recognized by epithelial cells and leukocytes. After ascending through the urethra, CT interacts and infects epithelial cells. Extracellular CT EBs are recognized by epithelial cells by toll-like receptors (TLR) 1, 2, 4 and 6, thus triggering TLR signalling and nuclear factor kappa-light-chain-enhancer of activated B cells (NFKB) nucleous translocation leading to proinflammatory gene expression and secretion. CT recognition by epithelial cells is strictly dependent on the adaptor molecule myeloid differentiation primary response 88 (MyD88), suggesting that other MyD88-dependent PRRs may be involved. It is believed that intracellular TLR2, TLR4 and TLR9 from epithelial cells may also have a role in CT recognition and so initiating TLR signaling from this compartment. In addition, CD45+ leukocytes may encounter and recognize CT mainly by TLR2, 1, 6 and 4 resulting in cytokine/chemokine secretion, immune cell recruitment and inflammation. Also, CT activated tissue resident CD45+ leukocytes may interact with epithelial cells in order to augment and coordinate an effective specific immune response driven by Neutrophils, NK cells, Th1 T cells and B cells. In contrast, a Th2 driven immune response may result in non-protective leading to pathology. Also, continuous activation of TLR on epithelial cells and CD45+ leukocytes by a chronic CT infection may cause a state of chronic inflammation of the male and female genital tract, which may impair tissue normal function and possibly trigger immunepathology process in susceptible individuals. Black lines indicate intracellular signaling and dotted black lines indicate theoretical mechanisms. 
recognition receptors (PRRs) leading to nuclear factor kappa-light-chain-enhancer of activated B cells (NFKB), p38 MAP kinase pathway (P38) and c-Jun N-terminal kinases (JNK) activation and the production of proinflammatory cytokines and chemokines (Al-Mously \& Eley 2007, Mackern-Oberti et al. 2013). These immune mediators may activate resident leukocytes and recruit others from the periphery, which in turn modulate the adaptive immune response (O'Neill 2002, Sellami et al. 2014). These interactions between CT and the host are summarized in Figs 1 and 2.

Chlamydia trachomatis recognition by PRRs in the FGT has been extensively explored, whereas the knowledge about PRR expression and CT recognition in the MGT is limited. It has been proposed that PRRs signaling may converge in MyD88 and thus immunopathology would occur by this molecular signaling (Nagarajan et al. 2005, Chen et al. 2010). MyD88-deficient mice failed to develop a protective immune response during Chlamydia muridarum (CM) genital tract infection, while mounting a specific T helper type 2 (Th2)-like immunity. As expected, female infected MyD88 KO mice showed increased bacterial burden in the upper genital tract with severe pathology, associated with a reduction in IFN- $\gamma$ production by natural killer (NK) cells and decreased levels of IL-17, IL-18 and TNF- $\alpha$ (Chen et al. 2010, Nagarajan et al. 2011). In addition, in vitro studies indicated that nucleotide-binding oligomerization domain-containing protein 1(NOD1) participates in CT recognition leading to IL-8 production by FGT epithelial cells, which in turn may collaborate in the recruitment of leukocytes initiating the immune response (Buchholz \& Stephens 2008).

Different MGT tissues such as urethra, testis, epididymis, prostate and vas deferens express TLRs showing a specific tissue distribution (Al-Mously \& Eley 2007, Palladino et al. 2007, 2008, Mackern-Oberti et al. 2011a,b, Winnall et al. 2011). Indeed, primary cultures of cells from different MGT tissues actively produce chemokines when stimulated with different TLR ligands, including polyinosinic:polycytidylic acid (Poly I:C), CpG oligodeoxynucleotides (CpG), E. coli LPS and chlamydial LPS (Mackern-Oberti et al. 2011a). Furthermore, prostate cell primary cultures from TLR2/4 double $\mathrm{KO}$ mice displayed an altered chemokine production in response to $\mathrm{CM}$ infection (Mackern Oberti et al. 2011b). Interestingly, prostate cell primary cultures from MyD88 KO mice showed a more pronounced decrease in chemokine production than TLR2/4 double $\mathrm{KO}$ mice suggesting that an additional PRR is involved in CT recognition (Mackern Oberti et al. 2011b) (Fig. 2). Moreover, TLR2 and TLR4, but not TLR5, were recruited to the chlamydial inclusion vicinity, suggesting an active role of these receptors in bacterial recognition and activation of MGT epithelial cells (Mackern-Oberti et al. 2006). Urethral and prostate epithelial cells respond to
CT-producing IL- $1 \alpha$ and IL-6 in a tissue-specific pattern, suggesting a differential sensitivity to $\mathrm{CT}$ recognition that may be due to a particular TLRs expression (Al-Mously \& Eley 2007). These molecular mechanisms are summarized in Fig. 2 and Table 1.

Besides CT recognition by epithelial cells, it is important to consider bacteria recognition by resident leukocytes (Aflatoonian \& Fazeli 2008, Mackern Oberti et al. 2011b). In the FGT, it has been reported that resident macrophages were the main source of IL-1 $\beta$ in response to CT infection, which may collaborate with epithelial cells in mounting an immune response (Prantner et al. 2009). Both prostate resident leukocytes $\left(\mathrm{CD} 45^{+}\right.$sorted cells) and epithelial/stromal cells (CD45sorted cells) express genes involved in TLR signalling but exhibit different responses to CT infection (Mackern Oberti et al. 2011b). In fact, CD45 ${ }^{+}$and $\mathrm{CD} 45^{-}$cells from MyD88 KO mice do not respond to CT infection (Mackern Oberti et al. 2011b). However, while CT recognition by $\mathrm{CD} 45^{+}$cells is dependent on TLR2/TLR4, CD45- cells keep responding to CT, to a certain extent, independently of TLR2/TLR4, suggesting a crucial role of these cells in initiating an immune response against CT (Mackern Oberti et al. 2011b) (Fig. 2 and Table 1).

\section{Chlamydia trachomatis infection of dendritic cells}

CT can efficiently infect and replicate into human dendritic cells (DCs) leading to the production of proinflammatory cytokines such as IL-1, IL-6, IL-8, IL-12, IL-18 and TNF- $\alpha$ (Gervassi et al. 2004, Agrawal et al. 2013, Datta et al. 2014). Macrophages could also be infected by CT but displaying a different bacterial development such as non-conventional inclusion formation (Herweg \& Rudel 2016, Zuck et al. 2016). Recently, it has been reported CT could also complete its replication cycle in induced pluripotent stem cellderived macrophages (Yeung et al. 2017).

Chlamydial LPS and heat shock protein 60 (HSP60) were the first antigens described to be recognized by TLR2 and TLR4 expressed on monocytes and DCs (Vabulas et al. 2001, Prebeck et al. 2003). Similarly, macrophage infectivity potentiator has also been reported to be recognized by TLR2 on macrophages leading to the production of IL-1 $\beta$, TNF- $\alpha$, IL- 6 and IL-8 (Bas et al. 2008). Interestingly, chlamydial MOMP, a surfaceexposed antigen, has the ability to signal via TLR2 in TLR-expressing transfected cells and in TLR2-competent endocervical End/E6E7 cells leading to IL-8 and IL-6 production (Massari et al. 2013). Although the molecular mechanisms underlying cellular recognition remain to be determined, several polymorphic membrane proteins induce innate immune responses (Vasilevsky et al. 2016). Chlamydial lipoproteins D381, D541 and D775 induce the production of pro-inflammatory cytokines mediated by TLR1/2/MyD88 and TLR2/CD14/MyD88 signaling 
Table 1 Innate immune mediators involved in CT infection of the genital tract.

\begin{tabular}{|c|c|c|c|c|c|}
\hline $\begin{array}{l}\text { Innate } \\
\text { immunity }\end{array}$ & Tissue & Cell type & Type of study & Response & References \\
\hline TLR2 & $\begin{array}{l}\text { MGT; FGT; } \\
\text { leukoctes }\end{array}$ & $\begin{array}{l}\text { Epithelial cells; } \\
\text { prostate; seminal } \\
\text { vesicles; vas } \\
\text { deferens; oviduct } \\
\text { cells; cervical } \\
\text { cells; leukocytes }\end{array}$ & $\begin{array}{l}\text { in vitro; in vivo; mice; } \\
\text { rat; human }\end{array}$ & $\begin{array}{l}\text { Cytokine and chemokine } \\
\text { production (TNF- } \alpha, \text { IL } 1-\beta, \text { IL-6, } \\
\text { IL-8, KC, MCP1, IL-12); involved } \\
\text { in immunity and } \\
\text { immunopathology; binding of } \\
\text { chlamydial LPS, HSP60, Mip } \\
\text { and MOMP }\end{array}$ & $\begin{array}{l}\text { Mackern-Oberti et al. (2006, } \\
\text { 2011a,b, 2013); Al-Mously } \\
\text { and Eley (2007); Massari et al. } \\
\text { (2013); Bas et al. (2008); } \\
\text { Sellami et al. (2014); } \\
\text { Palladino et al. (2007, 2008); } \\
\text { O'Neill (2002) }\end{array}$ \\
\hline TLR4 & $\begin{array}{l}\text { MGT; FGT; } \\
\text { leukoctes }\end{array}$ & $\begin{array}{l}\text { Epithelial cells; } \\
\text { prostate; seminal } \\
\text { vesicles; vas } \\
\text { deferens; oviduct } \\
\text { cells; cervical cells; } \\
\text { leukocytes }\end{array}$ & $\begin{array}{l}\text { in vitro; in vivo; mice; } \\
\quad \text { human }\end{array}$ & $\begin{array}{l}\text { Cytokine and chemokine } \\
\text { production; no major impact } \\
\text { in vivo; binding to LPS and } \\
\text { HSP60 }\end{array}$ & $\begin{array}{l}\text { Mackern-Oberti et al. (2006, } \\
\text { 2011a,b); Al-Mously \& Eley } \\
\text { (2007); Sellami et al. (2014); } \\
\text { O'Neill (2002) }\end{array}$ \\
\hline TLR3 & FGT & Cervical cells & in vitro; mouse & $\begin{array}{l}\text { Cytokine production; TLR3 } \\
\text { deficient leads to more } \\
\text { suscptibility to replication }\end{array}$ & Aflatoonian \& Fazeli (2008) \\
\hline TLR5 & MGT & Prostate & in vitro; rat & No major impact in vitro & $\begin{array}{l}\text { Mackern-Oberti et al. (2006); } \\
\quad \text { Palladino et al. }(2007,2008)\end{array}$ \\
\hline MyD88 & MGT; FGT & $\begin{array}{l}\text { Prostate; leukocytes; } \\
\text { cervical cells, } \\
\text { oviduct }\end{array}$ & in vitro; in vivo; mouse & $\begin{array}{l}\text { Involved in innate and adaptive } \\
\text { immune response, oviduct } \\
\text { pathology; MyD88 KO develop } \\
\text { a Th2 immunity; IFN-g reduction }\end{array}$ & $\begin{array}{l}\text { Mackern-Oberti et al. (2011a,b, } \\
\text { 2013); Nagarajan et al. (2005, } \\
\text { 2011); Chen et al. (2010); } \\
\text { O'Neill (2002) }\end{array}$ \\
\hline STAT1 & FGT & Cervical cells, oviduct & in vitro; mouse & $\begin{array}{l}\text { Contribute to IL-1 } \beta \text { response in CT } \\
\text { infection }\end{array}$ & Prantner et al. (2009) \\
\hline NOD1 & FGT & Cervical cells & $\begin{array}{l}\text { in vitro; mouse; human } \\
\text { genetic studies }\end{array}$ & $\begin{array}{l}\text { Contribute to IL-8 response in CT } \\
\text { infection; certain polymorphism } \\
\text { may confer lower risk of } \\
\text { infection }\end{array}$ & Buchholz \& Stephens (2008) \\
\hline
\end{tabular}

but not by TLR4 pathway (Wang et al. 2017) (Table 1). Interestingly, vaccination with chlamydial membrane proteins such as highly conserved type III secretion system (T3SS) proteins CopB, CopD and CT584 and MOMP induce neutralizing antibodies, enhance $T$ cell responses and reduce bacterial load from the vagina (Cheng et al. 2014, Pal et al. 2015, Bulir et al. 2016, de la Maza et al. 2017).

When TLR4 engagement is abrogated by a blocking monoclonal antibody, DCs fail to produce IL-1, IL-6 and TNF- $\alpha$ in response to CT (Gervassi et al. 2004). Surprisingly, adoptive transfer of mice with long-term infected DCs caused an in vivo infection showing that infective CT also develops within DCs and may be a potential reservoir with still unknown evasion mechanisms (Rey-Ladino et al. 2007, Rescigno 2015).

Interestingly, only viable EBs induce DC maturation with classical upregulation of major histocompatibility complex 2 (MHC-II), CD40, CD80, CD83, CD86 and intercellular adhesion molecule 1 (ICAM-1) expression, production of high levels of IL-12, TNF- $\alpha$, keratinocyte chemoattractant (KC), macrophage inflammatory protein 2 (MIP-2) and enhancing T cell priming (ReyLadino et al. 2005, Zaharik et al. 2007, Agrawal et al. 2013). Although much work has been done in mice and human monocytes, macrophages and DCs, it is important to note that resident myeloid cells from genital tract may display different immune response (Da Silva \& Barton 2016).

\section{Chlamydia trachomatis and the adaptive immune response}

Although CT-infected hosts develop adaptive immune responses, the bacterium manages to evade host immune effectors by building a niche inside epithelial cells (Igietseme \& Rank 1991, Bragina et al. 2001, Kokab et al. 2010). As previously mentioned, epithelial cells and resident leukocytes could secrete a wide spectrum of pro-inflammatory chemokines after CT recognition leading to the local recruitment of leukocytes (Deruaz \& Luster 2015). Both humoral and cell-mediated immune responses have been implicated in inducing protection against CT infection (Morrison et al. 2000, Loomis \& Starnbach 2002). It has been extensively demonstrated that the T cell-mediated immune response is crucial for protection, as T cell or MHC-II-deficient mice develop more severe and long-lasting CT infections (Rank et al. 1985, Morrison et al. 1995) (Table 2).

Most studies indicate that the Th1/IFN- $\gamma$ response is crucial for controlling CT infection (Cocchiaro et al. 2008, Li etal. 2008, Gondek etal. 2009). IFN- $\gamma$ R-deficient mice preferentially induce prominent Th2 responses and are susceptible to develop severe and long-lasting FGT infections (Gondek et al. 2009). In fact, macrophages from IFN- $\gamma$ R-deficient mice show increased numbers of intracellular CT inclusions and produce lower levels of nitric oxide (Johansson et al. 1997). Interestingly, in vitro studies suggest that IFN- $\gamma$ is crucial in mounting effector 
Table 2 Adaptive immune mediators involved in CT infection of the genital tract.

\begin{tabular}{|c|c|c|c|c|c|}
\hline $\begin{array}{l}\text { Adaptive } \\
\text { immunity }\end{array}$ & Tissue & Cell type & Type of study & Response & References \\
\hline T cells & FGT & $\begin{array}{l}\text { T cells; } \\
\text { cervical, } \\
\text { oviduct }\end{array}$ & in vivo; mouse & $\begin{array}{l}\text { T cells deficiency leads to } \mathrm{CT} \\
\text { chronic infection }\end{array}$ & $\begin{array}{l}\text { Loomis \& Starnbach (2002); Morrison et al. } \\
\text { (1995); Rank et al. (1985) }\end{array}$ \\
\hline $\begin{array}{l}\text { Th1; CD4+ T } \\
\text { cells; } \\
\text { cytokines; } \\
\text { IFN-g }\end{array}$ & $\begin{array}{l}\text { FGT; } \\
\text { MGT }\end{array}$ & $\begin{array}{l}\text { CD4+ T cells; } \\
\text { cervical, } \\
\text { oviduct }\end{array}$ & $\begin{array}{l}\text { in vivo; mouse; } \\
\text { human; human } \\
\text { genetic studies }\end{array}$ & $\begin{array}{l}\text { IFN- is crucial for immune } \\
\text { protection to CT infection by } \\
\text { differrent mechanisms } \\
\text { includding epithelial cell } \\
\text { activation; certain IL-12 } \\
\text { polymorphisms confer more risk } \\
\text { to infection; Th1 cells may reside } \\
\text { indiffernt sites of FGT and also } \\
\text { be modulated by Estrogen }\end{array}$ & $\begin{array}{l}\text { Kokab et al. (2010); Deruaz \& Luster (2015); } \\
\text { Morrison et al. (2000); Johansson et al. } \\
\text { (1997); Al-Zeer et al. (2009); Barral et al. } \\
\text { (2014); Cohen et al. (2005); } \\
\text { Cocchiaro et al. (2008); Gondek et al. } \\
\text { (2009); Li et al. (2008); Pal et al. (2010); } \\
\text { Davila et al. (2014); Su et al. (2004); } \\
\text { Mackern-Oberti et al. (2011c); Shao et al. } \\
\text { (2012) }\end{array}$ \\
\hline Th2; IL-4 & FGT & $\begin{array}{l}\text { CD4+ T cells; } \\
\text { cervical, } \\
\text { oviduct }\end{array}$ & $\begin{array}{l}\text { in vivo; mouse; } \\
\text { human }\end{array}$ & $\begin{array}{l}\text { Th2 leads to developing unresolve } \\
\text { infections; more susceptibility to } \\
\text { tubal factor infertility }\end{array}$ & $\begin{array}{l}\text { Johansson et al. (1997); Agrawal et al. } \\
\text { (2009); Vicetti Miguel et al. (2013); } \\
\text { Hawkins et al. (2002) }\end{array}$ \\
\hline $\begin{array}{l}\text { Th17; IL-17; } \\
\text { IL23 }\end{array}$ & FGT & $\begin{array}{l}\text { CD4+ T cells; } \\
\text { cervical, } \\
\text { oviduct }\end{array}$ & $\begin{array}{l}\text { in vivo; mouse; } \\
\text { human }\end{array}$ & $\begin{array}{l}\text { IL-17 deficiency leads to a } \\
\text { decreased Th1 immunity; TNF- } \alpha \\
\text { as a compensatory cytokine; } \\
\text { partially involved in oviduct } \\
\text { immunopathology; infection } \\
\text { course unaffected }\end{array}$ & $\begin{array}{l}\text { Scurlock et al. (2011); Nagarajan et al. } \\
\text { (2011); Frazer et al. (2013); O'Meara et al. } \\
\text { (2014); Yu et al. (2010); Andrew et al. } \\
\text { (2013); Vicetti Miguel et al. (2013); } \\
\text { Russell et al. (2016) }\end{array}$ \\
\hline CD8+ T cells & FGT & $\begin{array}{l}\text { CD8+ T cells; } \\
\text { cervical, } \\
\text { oviduct }\end{array}$ & $\begin{array}{l}\text { in vivo; mouse; } \\
\quad \text { human }\end{array}$ & $\begin{array}{l}\text { Controversial role of CD8+ T cells } \\
\text { in CT immunity; involved in } \\
\text { immunopathogenesis }\end{array}$ & $\begin{array}{l}\text { Deruaz \& Luster (2015); Agrawal et al. } \\
\text { (2009); Mittal et al. (2004); Vlcek et al. } \\
\text { (2015); Manam et al. (2013, 2015); } \\
\text { Nogueira et al. (2015) }\end{array}$ \\
\hline
\end{tabular}

mechanisms by promoting the accumulation of different interferon- $\gamma$-inducible regulatory immunity-related GTPase (Irg) molecules such as Irga6, Irgd, Irgm2 and Irgm3 at the chlamydial inclusion, targeting this vacuole to lysosomes for degradation (Al-Zeer et al. 2009) (Table 2). In mice, furthermore, Irga6-deficient cells are more susceptible to CT infection and fail to respond to IFN- $\gamma$ indicating that Irga6 is crucial for mounting an IFN- $\gamma$ response (Al-Zeer et al. 2009). Although studies evaluating cell-mediated immune responses to CT infection in humans are limited, a protective response associated to a reduced risk of pathology and reinfection is related to the Th1/CD4+ T cells/IFN- $\gamma$ axis (Barral et al. 2014). It has been reported that IFN- $\gamma$ production by CD4+ T cells in response to chlamydial HSP60 is associated to protection against CT (Cohen et al. 2005) (Table 2). In MGT, it remains to be determined whether Th1/IFN- $\gamma$ axis is involved in CT resistance (Pal et al. 2010). Nevertheless, researchers must be cautious when interpreting data obtained from the mouse model, especially when using its natural pathogen CM instead of $C T$, because of differences in bacterial replication and host recognition $\left(\mathrm{O}^{\prime}\right.$ Connell et al. 2011).

Gradual loss of protective immunity against CT generally occurs and is consistent with decreased CD4+ T cell numbers in the genital tract (Ramsey et al. 1989, Kelly \& Rank 1997). CD4 ${ }^{+} \mathrm{T}$ cells that are recruited to the female upper genital tract highly express a heterodimeric integrin receptor a $4 \beta 7$ and the blockage of this homing receptor leads to severe infection. The latter highlights the need of a vaccine that promotes a long-term expression of this adhesion molecule on
CT-specific Th1 $\mathrm{CD}^{+}$cells (Davila et al. 2014). Th2specific $T$ cells fail to induce protective immunity against CT displaying lower expression levels of this homing receptor (Hawkins et al. 2002). However, in an experimental model of CT infection of the MGT using C57BL/6 mice, it was reported that Th2-like cells transfer controls CT infection and prevents tissue damage (Sobinoff et al. 2015).

During the last years, the role for the Th17/IL-17 axis in the resolution of CT infection has also been investigated (Scurlock et al. 2011, Andrew et al. 2013, Frazer et al. 2013, Vicetti Miguel et al. 2013). Interestingly, IL-17-R-deficient mice showed a reduced Th1/IFN- $\gamma$ response against CT although they efficiently cleared the infection and displayed a more robust TNF$\alpha$-induced immune response with similar severity of oviductal pathology (Scurlock et al. 2011). By contrast, $\mathrm{CT}$-infected IFN- $\boldsymbol{\gamma}$-deficient mice showed a more severe immunopathology with higher levels of IL-17 that may contribute to misbalance the Th profiles (Scurlock et al. 2011). Immunization protocols indicate that Th17 responses collaborate with both, the induction of immune protection and development of FGT pathology (Yu et al. 2010, O'Meara et al. 2014).

Regarding cytotoxic T cells, it has been reported that CD8+ $\mathrm{T}$ cells are also recruited to the infected mucosa but their role in the infection resolution is still under debate (Mittal et al. 2004, Agrawal et al. 2009). After CT infection, $\mathrm{CD} 8^{+} \mathrm{T}$ cells contribute to oviductal pathology secreting TNF- $\alpha$ (Manam et al. 2015). In addition, adoptive $\mathrm{CD}^{+} \mathrm{T}$ cell transfer experiments showed that $\mathrm{CT}$-specific $\mathrm{CD}^{+} \mathrm{T}$ cells mediate immunopathogenesis 
in the FGT during CT infection (Manam et al. 2013, Vlcek et al. 2015). However, immunization protocols indicate that $\mathrm{CD} 8+\mathrm{T}$ cell response may mediate immune protection against CT (Nogueira et al. 2015). Additionally, women with lower FGT infection exhibit higher numbers of Chlamydia-specific CD8+ T cells than those with upper FGT infection (Russell et al. 2016) More compelling data are currently needed to ascertain the precise role of CD8+ T cells in CT infection of the genital tract (Table 2).

Pal and coworkers by inoculating male wild-type and severe combined immunodeficient mice showed the induction of a Th1 immune response and the requirement of the adaptive immune response to clear the bacterium from MGT (Pal et al. 2004, Su et al. 2004). CT infection of the MGT actively induces $\mathrm{CD}^{+}$and $\mathrm{CD}^{+} \mathrm{T}$ cell recruitment to the prostate gland, which is similar to that observed in infected women with PID (MackernOberti et al. 2011c, Shao et al. 2012). We have also reported for the first time that chronic MGT infection with CM may promote the loss of immune tolerance to prostate antigens (Mackern-Oberti et al. 2011c). These findings could help in understanding the underlying mechanisms of chronic pelvic pain syndrome and chronic prostatitis (Table 2).

\section{Conclusions}

CT modifies intracellular trafficking by modulating several host molecules in order to avoid degradation by phagocytosis, a major mechanism of the innate immune system. By using the same strategy, CT not only evades lysosome fusion but also redirects nutrient-rich vesicles to the chlamydial inclusion. CT also avoids degradative host cell response by inhibiting transcription factors and preventing apoptotic cell death. CT infection of the FGT and MGT induces the production of cytokines/ chemokines by epithelial cells and leukocytes that may initiate the specific adaptive immune response as well as drive immunopathology in susceptible hosts. Understanding Th1-driven immune response and identifying key CT targets at the genital tract are crucial for designing an efficient vaccine to control chlamydial transmission and disease, and thereby remain as major priority in CT research.

\section{Declaration of interest}

The authors declare that there is no conflict of interest that could be perceived as prejudicing the impartiality of the research reported.

\section{Funding}

This work was supported by Fundación Alberto J Roemmers 2016, Fundación Alberto J Roemmers 2016/17; PIP 0863/ 12
CONICET, SeCTyP 201606/M070 Universidad Nacional de Cuyo; Universidad Juan Agustín Maza, Secretaría de Ciencia y Técnica; SeCyT UNC 2016/17; ANPCYT PICT2015-0271, FONCYT PICT2012-2116, PICT-2014-2238, PICT 2013-2201, PICT 2014-1544; Bunge\&Born Foundation; Secyt-Universidad Nacional de Córdoba.

\section{References}

Aflatoonian R \& Fazeli A 2008 Toll-like receptors in female reproductive tract and their menstrual cycle dependent expression. Journal of Reproductive Immunology 77 7-13. (doi:10.1016/j.jri.2007.03.014)

Agrawal T, Vats V, Salhan S \& Mittal A 2009 Determination of chlamydial load and immune parameters in asymptomatic, symptomatic and infertile women. FEMS Immunology and Medical Microbiology 55 250-257. (doi:10.1111/j.1574-695X.2008.00530.x)

Agrawal T, Bhengraj A, Vats V \& Mittal A 2013 Chlamydia trachomatis: TLR4-mediated recognition by human dendritic cells is impaired following oestradiol treatment. British Journal of Biomedical Science 70 51-57. (doi:10.1080/09674845.2013.11669935)

Al-Mously N \& Eley A 2007 Interaction of Chlamydia trachomatis serovar E with male genital tract epithelium results in secretion of proinflammatory cytokines. Journal of Medical Microbiology 56 1025-1032. (doi:10.1099/ jmm.0.47241-0)

Al-Zeer MA, Al-Younes HM, Braun PR, Zerrahn J \& Meyer TF 2009 IFN- $\gamma$ inducible Irga6 mediates host resistance against Chlamydia trachomati via autophagy. PLoS ONE 4 e4588. (doi:10.1371/journal.pone.0004588)

Andrew DW, Cochrane M, Schripsema JH, Ramsey KH, Dando SJ, O'Meara CP, Timms P \& Beagley KW 2013 The duration of Chlamydia muridarum genital tract infection and associated chronic pathological changes are reduced in IL-17 knockout mice but protection is not increased further by immunization. PLOS ONE 8 e76664. (doi:10.1371/ journal.pone.0076664)

Barker JR, Koestler BJ, Carpenter VK, Burdette DL, Waters CM, Vance RE \& Valdivia RH 2013 STING-dependent recognition of cyclic di-AMP mediates type I interferon responses during Chlamydia trachomatis infection. MBio 4 e00018-e00013. (doi:10.1128/mbio.00018-13)

Barral R, Desai R, Zheng X, Frazer LC, Sucato GS, Haggerty CL, O'Connell CM, Zurenski MA \& Darville T 2014 Frequency of Chlamydia trachomatis-specific $T$ cell interferon- $\gamma$ and interleukin-17 responses in CD4-enriched peripheral blood mononuclear cells of sexually active adolescent females. Journal of Reproductive Immunology 103 29-37. (doi:10.1016/j.jri.2014.01.002)

Bas S, Neff L, Vuillet M, Spenato U, Seya T, Matsumoto M \& Gabay C 2008 The proinflammatory cytokine response to chlamydia trachomatis elementary bodies in human macrophages is partly mediated by a lipoprotein, the macrophage infectivity potentiator, through TLR2/TLR1/ TLR6 and CD14. Journal of Immunology 180 1158-1168. (doi:10.4049/ jimmunol.180.2.1158)

Beatty W, Morrison R \& Byrne G 1994a Persistent chlamydiae: from cell culture to a paradigm for chlamydial pathogenesis. Microbiology Reviews 58 686-699.

Beatty WL, Byrne GI \& Morrison RP 1994b Repeated and persistent infection with Chlamydia and the development of chronic inflammation and disease. Trends Microbiology 2 94-98. (doi:10.1016/0966842X(94)90542-8)

Bragina EY, Gomberg MA \& Dmitriev GA 2001 Electron microscopic evidence of persistent chlamydial infection following treatment. Journal of the European Academy of Dermatology and Venereology 15 405-409. (doi:10.1046/j.1468-3083.2001.00342.x)

Buchholz KR \& Stephens RS 2008 The cytosolic pattern recognition receptor NOD1 induces inflammatory interleukin-8 during Chlamydia trachomatis infection. Infection and Immunity $\mathbf{7 6}$ 3150-3155. (doi:10.1128/IAI.00104-08)

Bulir DC, Liang S, Lee A, Chong S, Simms E, Stone C, Kaushic C, Ashkar A \& Mahony JB 2016 Immunization with chlamydial type III secretion antigens reduces vaginal shedding and prevents fallopian tube pathology following live C. muridarum challenge. Vaccine 34 3979-3985. (doi:10.1016/j.vaccine.2016.06.046) 
Byrne GI, Lehmann LK \& Landry GJ 1986 Induction of tryptophan catabolism is the mechanism for gamma-interferon-mediated inhibition of intracellular Chlamydia psittaci replication in T24 cells. Infection and Immunity 53 347-351.

Campbell LA, Lee A \& Kuo C-C 2006 Cleavage of the N-linked oligosaccharide from the surfaces of Chlamydia species affects infectivity in the mouse model of lung infection. Infection and Immunity $\mathbf{7 4}$ 3027-3029. (doi:10.1128/IAI.74.5.3027-3029.2006)

Capmany A \& Damiani MT 2010 Chlamydia trachomatis intercepts Golgiderived sphingolipids through a Rab14-mediated transport required for bacterial development and replication. PLOS ONE 5 e14084. (doi:10.1371/journal.pone.0014084)

Cocchiaro JL, Kumar Y, Fischer ER, Hackstadt T \& Valdivia RH 2008 Cytoplasmic lipid droplets are translocated into the lumen of the Chlamydia trachomatis parasitophorous vacuole. PNAS 105 9379-9384. (doi:10.1073/pnas.0712241105)

Cohen CR, Koochesfahani KM, Meier AS, Shen C, Karunakaran K, Ondondo B, Kinyari T, Mugo NR, Nguti R \& Brunham RC 2005 Immunoepidemiologic profile of Chlamydia trachomatis infection: importance of heat-shock protein 60 and interferon- $\gamma$. Journal of Infectious Diseases 192 591-599. (doi:10.1086/432070)

Conant CG \& Stephens RS 2007 Chlamydia attachment to mammalian cells requires protein disulfide isomerase. Cell Microbiology 9 222-232. (doi:10.1111/j.1462-5822.2006.00783.x)

Chen L, Lei L, Chang X, Li Z, Lu C, Zhang X, Wu Y, Yeh I-T \& Zhong G 2010 Mice deficient in MyD88 develop a Th2-Dominant response and severe pathology in the upper genital tract following Chlamydia muridarum infection. Journal of Immunology 184 2602-2610. (doi:10.4049/ jimmunol.0901593)

Cheng C, Pal S, Tifrea D, Jia Z \& de la Maza LM 2014 A vaccine formulated with a combination of TLR-2 and TLR-9 adjuvants and the recombinant major outer membrane protein elicits a robust immune response and significant protection against a Chlamydia muridarum challenge. Microbes and Infection 16 244-252. (doi:10.1016/j.micinf.2013.11.009)

Da Silva N \& Barton CR 2016 Macrophages and dendritic cells in the posttesticular environment. Cell Tissue Research 363 97-104. (doi:10.1007/ s00441-015-2270-0)

Damiani MT, Gambarte Tudela J \& Capmany A 2014 Targeting eukaryotic Rab proteins: a smart strategy for chlamydial survival and replication. Cell Microbiology 16 1329-1338. (doi:10.1111/cmi.12325)

Datta B, Njau F, Thalmann J, Haller H \& Wagner A 2014 Differential infection outcome of Chlamydia trachomatis in human blood monocytes and monocyte-derived dendritic cells. BMC Microbiology 14209. (doi:10.1186/s12866-014-0209-3)

Davila SJ, Olive AJ \& Starnbach MN 2014 Integrin $\alpha 4 \beta 1$ Is Necessary for CD4+ T Cell-Mediated Protection against Genital Chlamydia trachomatis infection. Journal of Immunology 192 4284-4293. (doi:10.4049/jimmunol.1303238)

de Jesus De Haro-Cruz $M$, Deleon-Rodriguez I, Escobedo-Guerra MR, Lopez-Hurtado M, Arteaga-Troncoso G, Ortiz-Ibarra FJ \& Guerra-Infante FM 2011 Genotyping of Chlamydia trachomatis from endocervical specimens of infertile Mexican women. Enfermedades Infecciosas y Microbiología Clínica 29 102-108. (doi:10.1016/j. eimc.2010.08.014)

de la Maza LM, Zhong G \& Brunham RC 2017 Update on Chlamydia trachomatis Vaccinology. Clinical and Vaccine Immunology 24 00543-00516. (doi:10.1128/cvi.00543-16)

Derre I, Swiss R \& Agaisse H 2011 The lipid transfer protein CERT interacts with the Chlamydia inclusion protein IncD and participates to ER-Chlamydia inclusion membrane contact sites. PLoS Pathogens 7 e1002092. (doi:10.1371/journal.ppat.1002092)

Deruaz M \& Luster AD 2015 Chemokine-mediated immune responses in the female genital tract mucosa. Immunology and Cell Biology 93 347-354. (doi:10.1038/icb.2015.20)

Elwell CA, Ceesay A, Kim JH, Kalman D \& Engel JN 2008 RNA interference screen identifies Abl kinase and PDGFR signaling in Chlamydia trachomatis entry. PLoS Pathogens 4 e1000021. (doi:10.1371/journal. ppat.1000021)

Elwell CA, Jiang S, Kim JH, Lee A, Wittmann T, Hanada K, Melancon P \& Engel JN 2011 Chlamydia trachomatis co-opts GBF1 and CERT to acquire host sphingomyelin for distinct roles during intracellular development. PLoS Pathogens 7 e1002198. (doi:10.1371/journal.ppat.1002198)
Elwell C, Mirrashidi K \& Engel J 2016 Chlamydia cell biology and pathogenesis. Nature Reviews Microbiology 14 385-400. (doi:10.1038/ nrmicro.2016.30)

Fadel S \& Eley A 2007 Chlamydia trachomatis OmcB protein is a surfaceexposed glycosaminoglycan-dependent adhesin. Journal of Medical Microbiology 56 15-22. (doi:10.1099/jmm.0.46801-0)

Finethy R, Jorgensen I, Haldar AK, de Zoete MR, Strowig T, Flavell RA, Yamamoto M, Nagarajan UM, Miao EA \& Coers J 2015 Guanylate binding proteins enable rapid activation of canonical and noncanonical inflammasomes in Chlamydia-infected macrophages. Infection and Immunity 83 4740-4749. (doi:10.1128/IAI.00856-15)

Frazer LC, Scurlock AM, Zurenski MA, Riley MM, Mintus M, Pociask DA, Sullivan JE, Andrews CW \& Darville T 2013 IL-23 Induces IL-22 and IL-17 production in response to Chlamydia muridarum genital tract infection, but the absence of these cytokines does not influence disease pathogenesis. American Journal of Reproductive Immunology 70 472-484. (doi:10.1111/aji.12171)

Furuya R, Takahashi S, Furuya S, Takeyama K \& Tsukamoto T 2005 A patient with seminal vesiculitis prior to acute chlamydial epididymitis. Journal of Infection and Chemotherapy 11 250-252. (doi:10.1007/s10156-0050404-0)

Furuya R, Takahashi S, Furuya S, Saitoh N, Ogura H, Kurimura Y \& Tsukamoto T 2009 Is urethritis accompanied by seminal vesiculitis? International Journal of Urology 16 628-631. (doi:10.1111/j.14422042.2009.02314.x)

Gambarte Tudela J, Capmany A, Romao M, Quintero C, Miserey-Lenkei S, Raposo G, Goud B \& Damiani MT 2015 The late endocytic Rab39a GTPase regulates the interaction between multivesicular bodies and chlamydial inclusions. Journal of Cell Science 128 3068-3081. (doi:10.1242/jcs.170092)

Gervassi A, Alderson MR, Suchland R, Maisonneuve JF, Grabstein KH \& Probst P 2004 Differential regulation of inflammatory cytokine secretion by human dendritic cells upon Chlamydia trachomatis infection. Infection and Immunity 72 7231-7239. (doi:10.1128/IAI.72.12.72317239.2004)

Gondek DC, Roan NR \& Starnbach MN 2009 T cell responses in the absence of IFN-gamma exacerbate uterine infection with Chlamydia trachomatis. Journal of Immunology 183 1313-1319. (doi:10.4049/ jimmunol.0900295)

Gottlieb SL, Berman SM \& Low N 2010 Screening and treatment to prevent sequelae in women with Chlamydia trachomatis genital infection: how much do we know? Journal of Infectious Diseases 201 S156-S167. (doi:10.1086/652396)

Gottlieb SL, Xu F \& Brunham RC 2013 Screening and treating chlamydia trachomatis genital infection to prevent pelvic inflammatory disease: interpretation of findings from randomized controlled trials. Sexually Transmitted Diseases 40 97-102. (doi:10.1097/ OLQ.1090b1013e31827bd31637)

Hackstadt T 2012 Intracellular pathogens I: Chlamydiales, pp. 126-148. Ed M Tan. Washington, DC: ASM Press.

Haggerty CL, Gottlieb SL, Taylor BD, Low N, Xu F \& Ness RB 2010 Risk of Sequelae after Chlamydia trachomatis Genital Infection in Women. Journal of Infectious Diseases 201 S134-S155. (doi:10.1086/652395)

Hawkins RA, Rank RG \& Kelly KA 2002 A Chlamydia trachomatisSpecific Th2 Clone Does Not Provide Protection against a Genital Infection and Displays Reduced Trafficking to the Infected Genital Mucosa. Infection and Immunity 70 5132-5139. (doi:10.1128/ IAI.70.9.5132-5139.2002)

Herweg JA \& Rudel T 2016 Interaction of Chlamydiae with human macrophages. FEBS Journal 283 608-618. (doi:10.1111/febs.13609)

Igietseme, JU \& Rank RG 1991 Susceptibility to reinfection after a primary chlamydial genital infection is associated with a decrease of antigen-specific $\mathrm{T}$ cells in the genital tract. Infection and Immunity $\mathbf{5 9}$ 1346-1351.

Johansson M, Schon K, Ward M \& Lycke N 1997 Genital tract infection with Chlamydia trachomatis fails to induce protective immunity in gamma interferon receptor-deficient mice despite a strong local immunoglobulin A response. Infection and Immunity 65 1032-1044.

Kelly KA \& Rank RG 1997 Identification of homing receptors that mediate the recruitment of CD4 T cells to the genital tract following intravaginal infection with Chlamydia trachomatis. Infection and Immunity $\mathbf{6 5}$ 5198-5208. 
Kim JH, Jiang S, Elwell CA \& Engel JN 2011 Chlamydia trachomatis coopts the FGF2 signaling pathway to enhance infection. PLoS Pathogens 7 e1002285. (doi:10.1371/journal.ppat.1002285)

Kokab A, Jennings R, Eley A, Pacey AA \& Cross NA 2010 Analysis of modulated gene expression in a model of Interferon- $\boldsymbol{\gamma}$-induced persistence of Chlamydia trachomatis in HEp-2 cells. Microbial Pathogenesis 49 217-225. (doi:10.1016/j.micpath.2010.06.002)

Kortekangas-Savolainen O, Makinen J, Koivusalo K \& Mattila K 2012 Hospital-diagnosed late sequelae after female Chlamydia trachomatis infections in 1990-2006 in Turku, Finland. Gynecologic and Obstetric Investigation 73 299-303. (doi:10.1159/000334822)

Kumar Y, Cocchiaro J \& Valdivia RH 2006 The obligate intracellular pathogen Chlamydia trachomatis targets host lipid droplets. Current Biology 16 1646-1651. (doi:10.1016/j.cub.2006.06.060)

Kun D, Xiang-Lin C, Ming Z \& Qi L 2013 Chlamydia inhibit host cell apoptosis by inducing Bag-1 via the MAPK/ERK survival pathway. Apoptosis 18 1083-1092. (doi:10.1007/s10495-013-0865-z)

Kuo C-C, Puolakkainen M, Lin T-M, Witte M \& Campbell LA 2002 Mannose-receptor positive and negative mouse macrophages differ in their susceptibility to infection by Chlamydia species. Microbial Pathogenesis 32 43-48. (doi:10.1006/mpat.2001.0479)

Lei L, Chen J, Hou S, Ding Y, Yang Z, Zeng H, Baseman J \& Zhong G 2014 Reduced live organism recovery and lack of hydrosalpinx in mice infected with plasmid-free Chlamydia muridarum. Infection and Immunity 82 983-992. (doi:10.1128/IAI.01543-13)

Leiva N, Capmany A \& Damiani MT 2013 Rab11-family of interacting protein 2 associates with chlamydial inclusions through its Rab-binding domain and promotes bacterial multiplication. Cell Microbiology 15 114-129. (doi:10.1111/cmi.12035)

Li W, Murthy AK, Guentzel MN, Seshu J, Forsthuber TG, Zhong G \& Arulanandam BP 2008 Antigen-specific CD4+ T cells produce sufficient IFN-gamma to mediate robust protective immunity against genital Chlamydia muridarum infection. Journal of Immunology $\mathbf{1 8 0}$ 3375-3382. (doi:10.4049/jimmunol.180.5.3375)

Loomis WP \& Starnbach MN 2002 T cell responses to Chlamydia trachomatis. Current Opinion in Microbiology 5 87-91. (doi:10.1016/ S1369-5274(02)00291-6)

Mackern-Oberti JP, Maccioni M, Cuffini C, Gatti G \& Rivero VE 2006 Susceptibility of prostate epithelial cells to Chlamydia muridarum infection and their role in innate immunity by recruitment of intracellular toll-like receptors 4 and 2 and MyD88 to the inclusion. Infection and Immunity 74 6973-6981. (doi:10.1128/IAI.00593-06)

Mackern-Oberti J, Maccioni M, Breser ML, Eley A, Miethke T \& Rivero VE 2011a Innate immunity in the male genital tract: Chlamydia trachomatis induces keratinocyte-derived chemokine production in prostate, seminal vesicle and epididymis/vas deferens primary cultures. Journal of Medical Microbiology 60 307-316. (doi:10.1099/jmm.0.024877-0)

Mackern Oberti JP, Breser ML, Nuñez N, Maccioni M, Rodríguez N, Wantia N, Ertl T, Miethke T \& Rivero VE 2011b Chemokine response induced by Chlamydia trachomatis in prostate derived CD45+ and CD45- cells. Reproduction 142 427-437. (doi:10.1530/REP-11-0163)

Mackern-Oberti JP, Motrich RD, Breser ML, Cejas H, Cuffini C, Maccioni M \& Rivero VE 2011c Male rodent genital tract infection with Chlamydia muridarum: persistence in the prostate gland that triggers self-immune reactions in genetically susceptible hosts. Journal of Urology $\mathbf{1 8 6}$ 1100-1106. (doi:10.1016/j.juro.2011.04.086)

Mackern-Oberti JP, Motrich RD, Breser ML, Sánchez LR, Cuffini C \& Rivero VE 2013 Chlamydia trachomatis infection of the male genital tract: An update. Journal of Reproductive Immunology 100 37-53. (doi:10.1016/j.jri.2013.05.002)

Manam S, Nicholson BJ \& Murthy AK 2013 OT-1 mice display minimal upper genital tract pathology following primary intravaginal Chlamydia muridarum infection. Pathogens and Disease 67 221-224. (doi:10.1111/2049-632X.12032)

Manam S, Thomas JD, Li W, Maladore A, Schripsema JH, Ramsey KH \& Murthy AK 2015 Tumor necrosis factor (TNF) receptor superfamily member $1 \mathrm{~b}$ on $\mathrm{CD} 8+\mathrm{T}$ cells and TNF receptor superfamily member 1a on Non-CD8+ T cells contribute significantly to upper genital tract pathology following chlamydial infection. Journal of Infectious Diseases 211 2014-2022. (doi:10.1093/infdis/jiu839)

Massari P, Toussi DN, Tifrea DF \& de la Maza LM 2013 Toll-like receptor 2-dependent activity of native major outer membrane protein proteosomes of Chlamydia trachomatis. Infection and Immunity $\mathbf{8 1}$ 303-310. (doi:10.1128/IAI.01062-12)

Menozzi FD, Pethe K, Bifani P, Soncin F, Brennan MJ \& Locht C 2002 Enhanced bacterial virulence through exploitation of host glycosaminoglycans. Molecular Microbiology $43 \quad 1379-1386$. (doi:10.1046/j.1365-2958.2002.02841.x)

Misaghi S, Balsara ZR, Catic A, Spooner E, Ploegh HL \& Starnbach MN 2006 Chlamydia trachomatis-derived deubiquitinating enzymes in mammalian cells during infection. Molecular Microbiology 61 142-150. (doi:10.1111/j.1365-2958.2006.05199.x)

Mittal A, Rastogi S, Reddy BS, Verma S, Salhan S \& Gupta E 2004 Enhanced immunocompetent cells in chlamydial cervicitis. Journal of Reproductive Medicine 49 671-677.

Moorhead AR, Rzomp KA \& Scidmore MA 2007 The Rab6 effector Bicaudal D1 associates with Chlamydia trachomatis inclusions in a biovarspecific manner. Infection and Immunity 75 781-791. (doi:10.1128/ IAI.01447-06)

Moorhead AM, Jung JY, Smirnov A, Kaufer S \& Scidmore MA 2010 Multiple host proteins that function in phosphatidylinositol-4-phosphate metabolism are recruited to the chlamydial inclusion. Infection and Immunity 78 1990-2007. (doi:10.1128/IAI.01340-09)

Morrison RP, Feilzer K \& Tumas DB 1995 Gene knockout mice establish a primary protective role for major histocompatibility complex class IIrestricted responses in Chlamydia trachomatis genital tract infection. Infection and Immunity 63 4661-4668.

Morrison SG, Su H, Caldwell HD \& Morrison RP 2000 Immunity to murine chlamydia trachomatis genital tract reinfection involves $\mathrm{B}$ cells and CD4+ T cells but not CD8+ T cells. Infection and Immunity 68 6979-6987. (doi:10.1128/IAI.68.12.6979-6987.2000)

Motrich RD, Sanchez L, Maccioni M, Mackern-Oberti JP \& Rivero VE 2012 Male rat genital tract infection with chlamydia muridarum has no significant consequence on male fertility. Journal of Urology 187 1911-1917. (doi:10.1016/j.juro.2011.12.055)

Mylonas I 2012 Female genital Chlamydia trachomatis infection: where are we heading? Archives of Gynecology and Obstetrics 285 1271-1285. (doi:10.1007/s00404-012-2240-7)

Nagarajan UM, Ojcius DM, Stahl L, Rank RG \& Darville T 2005 Chlamydia trachomatis induces expression of IFN- $\gamma$-inducible protein 10 and IFN- $\beta$ independent of TLR2 and TLR4, but largely dependent on MyD88. Journal of Immunology 175 450-460. (doi:10.4049/ jimmunol.175.1.450)

Nagarajan UM, Sikes J, Prantner D, Andrews CW, Frazer L, Goodwin A, Snowden JN \& Darville T 2011 MyD88 deficiency leads to decreased NK cell gamma interferon production and $T$ cell recruitment during Chlamydia muridarum genital tract infection, but a predominant Th1 response and enhanced monocytic inflammation are associated with infection resolution. Infection and Immunity 79 486-498. (doi:10.1128/ IAI.00843-10)

Nogueira CV, Zhang X, Giovannone N, Sennott EL \& Starnbach MN 2015 Protective immunity against Chlamydia trachomatis can engage both CD4+ and CD8+ T cells and bridge the respiratory and genital mucosae. Journal of Immunology 194 2319-2329. (doi:10.4049/ jimmunol.1402675)

O'Connell CM, Ingalls RR, Andrews CW Jr, Scurlock AM \& Darville T 2007 Plasmid-deficient Chlamydia muridarum fail to induce immune pathology and protect against oviduct disease. Journal of Immunology 179 4027-4034. (doi:10.4049/jimmunol.179.6.4027)

O'Connell CM, AbdeIRahman YM, Green E, Darville HK, Saira K, Smith B, Darville T, Scurlock AM, Meyer CR \& Belland RJ 2011 Toll-like receptor 2 activation by Chlamydia trachomatis is plasmid dependent, and plasmidresponsive chromosomal loci are coordinately regulated in response to glucose limitation by $\mathrm{C}$. trachomatis but not by C. muridarum. Infection and Immunity 79 1044-1056. (doi:10.1128/iai.01118-10)

O'Meara CP, Armitage CW, Harvie MCG, Andrew DW, Timms P, Lycke NY \& Beagley KW 2014 Immunity against a Chlamydia infection and disease may be determined by a balance of IL-17 signaling. Immunology Cell Biology 92 287-297. (doi:10.1038/icb.2013.92)

O'Neill LAJ 2002 Toll-like receptor signal transduction and the tailoring of innate immunity: a role for mal? Trends Immunology 23 296-300. (doi:10.1016/s1471-4906(02)02222-6)

Pal S, Peterson EM \& de la Maza LM 2004 New murine model for the study of Chlamydia trachomatis genitourinary tract infections in males. 
Infection and Immunity 72 4210-4216. (doi:10.1128/IAI.72.7.42104216.2004)

Pal S, Sarcon AK \& de la Maza LM 2010 A new murine model for testing vaccines against genital Chlamydia trachomatis infections in males. Vaccine 28 7606-7612. (doi:10.1016/j.vaccine.2010.09.060)

Pal S, Tatarenkova OV \& de la Maza LM 2015 A vaccine formulated with the major outer membrane protein can protect $\mathrm{C} 3 \mathrm{H} / \mathrm{HeN}$, a highly susceptible strain of mice, from a Chlamydia muridarum genital challenge. Immunology 146 432-443. (doi:10.1111/imm.12520)

Palladino MA, Johnson TA, Gupta R, Chapman JL \& Ojha P 2007 Members of the toll-like receptor family of innate immunity pattern-recognition receptors are abundant in the male rat reproductive tract. Biology Reproduction 76 958-964. (doi:10.1095/biolreprod.106.059410)

Palladino MA, Savarese MA, Chapman JL, Dughi M-K \& Plaska D 2008 Original article: localization of toll-like receptors on epididymal epithelial cells and spermatozoa. American Journal of Reproductive Immunology 60 541-555. (doi:10.1111/j.1600-0897.2008.00654.x)

Perry LL, Su H, Feilzer K, Messer R, Hughes S, Whitmire W \& Caldwell HD 1999 Differential sensitivity of distinct Chlamydia trachomatis isolates to IFN-gamma-mediated inhibition. Journal of Immunology 162 $3541-3548$

Prantner D, Darville T, Sikes JD, Andrews CWJ, Brade H, Rank RG \& Nagarajan UM 2009 Critical role for interleukin-1 beta (IL-1beta) during Chlamydia muridarum genital infection and bacterial replicationindependent secretion of IL-1beta in mouse macrophages. Infection and Immunity 77 5334-5346. (doi:10.1128/IAI.00883-09)

Prebeck S, Brade H, Kirschning CJ, da Costa CP, Dürr S, Wagner H \& Miethke T 2003 The Gram-negative bacterium Chlamydia trachomatis L2 stimulates tumor necrosis factor secretion by innate immune cells independently of its endotoxin. Microbes and Infection 5 463-470. (doi:10.1016/S1286-4579(03)00063-7)

Ramsey KH, Newhall WJ \& Rank RG 1989 Humoral immune response to chlamydial genital infection of mice with the agent of mouse pneumonitis. Infection and Immunity 57 2441-2446.

Rank RG, Soderberg LS \& Barron AL 1985 Chronic chlamydial genital infection in congenitally athymic nude mice. Infection and Immunity 48 847-849.

Refaat B, Ashshi AM, Batwa SA, Ahmad J, Idris S, Kutbi SY, Malibary FA \& Kamfar FF 2016 The prevalence of Chlamydia trachomatis and Mycoplasma genitalium tubal infections and their effects on the expression of IL-6 and leukaemia inhibitory factor in Fallopian tubes with and without an ectopic pregnancy. Innate Immunology 22 534-545. (doi:10.1177/1753425916662326)

Rejman Lipinski A, Heymann J, Meissner C, Karlas A, Brinkmann V, Meyer TF \& Heuer D 2009 Rab6 and Rab11 regulate Chlamydia trachomatis development and golgin-84-dependent Golgi fragmentation. PLOS Pathogens 5 e1000615. (doi:10.1371/journal.ppat.1000615)

Rescigno M 2015 Dendritic cell functions: learning from microbial evasion strategies. Semin Immunology 27 119-124. (doi:10.1016/j. smim.2015.03.012)

Rey-Ladino J, Koochesfahani KM, Zaharik ML, Shen C \& Brunham RC 2005 A live and inactivated Chlamydia trachomatis mouse pneumonitis strain induces the maturation of dendritic cells that are phenotypically and immunologically distinct. Infection and Immunity 73 1568-1577. (doi:10.1128/IAI.73.3.1568-1577.2005)

Rey-Ladino J, Jiang X, Gabel BR, Shen C \& Brunham RC 2007 Survival of Chlamydia muridarum within dendritic cells. Infection and Immunity $\mathbf{7 5}$ 3707-3714. (doi:10.1128/IAI.01618-06)

Russell AN, Zheng X, O'Connell CM, Wiesenfeld HC, Hillier SL, Taylor BD, Picard MD, Flechtner JB, Zhong W, Frazer LC et al. 2016 Identification of Chlamydia trachomatis antigens recognized by $\mathrm{T}$ cells from highly exposed women who limit or resist genital tract infection. Journal of Infectious Diseases 214 1884-1892. (doi:10.1093/infdis/jiw485)

Rzomp KA, Scholtes LD, Briggs BJ, Whittaker GR \& Scidmore MA 2003 Rab GTPases are recruited to chlamydial inclusions in both a speciesdependent and species-independent manner. Infection and Immunity $\mathbf{7 1}$ 5855-5870. (doi:10.1128/IAl.71.10.5855-5870.2003)

Rzomp KA, Moorhead AR \& Scidmore MA 2006 The GTPase Rab4 interacts with Chlamydia trachomatis inclusion membrane protein CT229. Infection and Immunity 74 5362-5373. (doi:10.1128/IAI.00539-06)

Saka HA \& Valdivia RH 2010 Acquisition of nutrients by Chlamydiae: unique challenges of living in an intracellular compartment. Current Opinion in Microbiology 13 4-10. (doi:10.1016/j.mib.2009.11.002)
Saka HA, Thompson JW, Chen YS, Dubois LG, Haas JT, Moseley A \& Valdivia RH 2015 Chlamydia trachomatis infection leads to defined alterations to the lipid droplet proteome in epithelial cells. PLOS ONE 10 e0124630. (doi:10.1371/journal.pone.0124630)

Scurlock AM, Frazer LC, Andrews CW, O'Connell CM, Foote IP, Bailey SL, Chandra-Kuntal K, Kolls JK \& Darville T 2011 Interleukin-17 contributes to generation of Th1 immunity and neutrophil recruitment during Chlamydia muridarum genital tract infection but is not required for macrophage influx or normal resolution of infection. Infection and Immunity 79 1349-1362. (doi:10.1128/IAI.00984-10)

Sellami H, Said-Sadier N, Znazen A, Gdoura R, Ojcius DM \& Hammami A 2014 Chlamydia trachomatis infection increases the expression of inflammatory tumorigenic cytokines and chemokines as well as components of the Toll-like receptor and NF-kB pathways in human prostate epithelial cells. Molecular and Cellular Probes 28 147-154. (doi:10.1016/j.mcp.2014.01.006)

Shao R, Wang X, Wang W, Stener-Victorin E, Mallard C, Brännström M \& Billig H 2012 From mice to women and back again: causalities and clues for Chlamydia-induced tubal ectopic pregnancy. Fertility and Sterility $\mathbf{9 8}$ 1175-1185. (doi:10.1016/j.fertnstert.2012.07.1113)

Sherchand S, Ibana JA, Quayle AJ \& Aiyar A 2016 Cell intrinsic factors modulate the effects of IFNgamma on the development of Chlamydia trachomatis. Journal of Bacteriology and Parasitology 7282. (doi:10.4172/2155-9597.1000282)

Sixt BS, Bastidas RJ, Finethy R, Baxter RM, Carpenter VK, Kroemer G, Coers J \& Valdivia RH 2017 The Chlamydia trachomatis inclusion membrane protein CpoS counteracts STING-mediated cellular surveillance and suicide programs. Cell Host and Microbe 21 113-121. (doi:10.1016/j. chom.2016.12.002)

Sobinoff AP, Dando SJ, Redgrove KA, Sutherland JM, Stanger SJ, Armitage CW, Timms P, McLaughlin EA \& Beagley KW 2015 Chlamydia muridarum infection-induced destruction of male germ cells and sertoli cells is partially prevented by Chlamydia major outer membrane protein-specific immune CD4 cells. Biology Reproduction 92 21-13. (doi:10.1095/biolreprod.114.124180)

Stallmann S \& Hegemann JH 2016 The Chlamydia trachomatis Ctad1 invasin exploits the human integrin beta1 receptor for host cell entry. Cell Microbiology 18 761-775. (doi:10.1111/cmi.12549)

Su, H, Raymond L, Rockey DD, Fischer E, Hackstadt T \& Caldwell HD 1996 A recombinant Chlamydia trachomatis major outer membrane protein binds to heparan sulfate receptors on epithelial cells. PNAS 93 11143-11148. (doi:10.1073/pnas.93.20.11143)

Su H, McClarty G, Dong F, Hatch GM, Pan ZK \& Zhong G 2004 Activation of Raf/MEK/ERK/CPLA2 signaling pathway is essential for chlamydial acquisition of host glycerophospholipids. Journal of Biological Chemistry 279 9409-9416. (doi:10.1074/jbc.M312008200)

Subbarayal P, Karunakaran K, Winkler AC, Rother M, Gonzalez E, Meyer TF \& Rudel T 2015 EphrinA2 receptor (EphA2) is an invasion and intracellular signaling receptor for Chlamydia trachomatis. PLoS Pathogens 11 e1004846. (doi:10.1371/journal.ppat.1004846)

Vabulas RM, Ahmad-Nejad P, da Costa C, Miethke T, Kirschning CJ, Häcker H \& Wagner H 2001 Endocytosed HSP60s use toll-like receptor 2 (TLR2) and TLR4 to activate the toll/interleukin-1 receptor signaling pathway in innate immune cells. Journal of Biological Chemistry $\mathbf{2 7 6}$ 31332-31339. (doi:10.1074/jbc.M103217200)

Valdivia RH 2008 Chlamydia effector proteins and new insights into chlamydial cellular microbiology. Current Opinion in Microbiology 11 53-59. (doi:10.1016/j.mib.2008.01.003)

Vasilevsky S, Stojanov M, Greub G \& Baud D 2016 Chlamydial polymorphic membrane proteins: regulation, function and potential vaccine candidates. Virulence 7 11-22. (doi:10.1080/21505594.2015. 1111509)

Vicetti Miguel RD, Harvey SAK, LaFramboise WA, Reighard SD, Matthews DB \& Cherpes TL 2013 Human female genital tract infection by the obligate intracellular bacterium Chlamydia trachomatis elicits robust type 2 immunity. PLOS ONE 8 e58565. (doi:10.1128/ IAI.00539-06)

Vlcek KR, Li W, Manam S, Zanotti B, Nicholson BJ, Ramsey KH \& Murthy AK 2015 The contribution of Chlamydia-specific CD8+ T cells to upper genital tract pathology. Immunology and Cell Biology 94 208-212. (doi:10.1038/icb.2015.74)

Wang Y, Liu Q, Chen D, Guan J, Ma L, Zhong G, Shu H \& Wu X 2017 Chlamydial lipoproteins stimulate toll-like receptors $1 / 2$ mediated 
inflammatory responses through MyD88-dependent pathway. Frontiers in Microbiology 8 e1006383. (doi:10.3389/fmicb.2017.00078)

Weber MM, Lam JL, Dooley CA, Noriea NF, Hansen BT, Hoyt FH, Carmody AB, Sturdevant GL \& Hackstadt T 2017 Absence of specific Chlamydia trachomatis inclusion membrane proteins triggers premature inclusion membrane lysis and host cell death. Cell Reports 19 1406-1417. (doi:10.1016/j.celrep.2017.04.058)

Webster SJ, Brode S, Ellis L, Fitzmaurice TJ, Elder MJ, Gekara NO, Tourlomousis P, Bryant C, Clare S, Chee R et al. 2017 Detection of a microbial metabolite by STING regulates inflammasome activation in response to Chlamydia trachomatis infection. PLOS Pathogens $\mathbf{1 3}$ (doi:10.1371/journal.ppat.1006383)

Wehrl W, Brinkmann V, Jungblut PR, Meyer TF \& Szczepek AJ 2004 From the inside out - processing of the Chlamydial autotransporter PmpD and its role in bacterial adhesion and activation of human host cells. Molecular Microbiology 51 319-334. (doi:10.1046/j.1365-2958.2003.03838.x)

WHO 2016 WHO Guidelines for the Treatment of Chlamydia trachomatis. World Health Organization.

Winnall WR, Muir JA \& Hedger MP 2011 Differential responses of epithelial Sertoli cells of the rat testis to Toll-like receptor 2 and 4 ligands: implications for studies of testicular inflammation using bacterial lipopolysaccharides. Innate Immunology 17 123-136. (doi:10.1177/1753425909354764)

Wyrick PB 2010 Chlamydia trachomatis persistence in vitro: an overview. Journal of Infectious Diseases 201 S88-S95. (doi:10.1086/652394)

Yang Z, Tang L, Shao L, Zhang Y, Zhang T, Schenken R, Valdivia R \& Zhong G 2016 The Chlamydia-secreted protease CPAF promotes chlamydial survival in the mouse lower genital tract. Infection and Immunity $\mathbf{8 4}$ 2697-2702. (doi:10.1128/IAI.00280-16)
Yeung ATY, Hale C, Lee AH, Gill EE, Bushell W, Parry-Smith D, Goulding D, Pickard D, Roumeliotis T, Choudhary J et al. 2017 Exploiting induced pluripotent stem cell-derived macrophages to unravel host factors influencing Chlamydia trachomatis pathogenesis. Nature Communications 8 15013. (doi:10.1038/ncomms15013)

Yu, H, Jiang X, Shen C, Karunakaran KP, Jiang J, Rosin NL \& Brunham RC 2010 Chlamydia muridarum T-Cell antigens formulated with the adjuvant DDA/TDB induce immunity against infection that correlates with a high frequency of gamma interferon (IFN- $\gamma$ )/tumor necrosis factor alpha and IFN- $\gamma /$ Interleukin-17 double-positive CD4+ T Cells. Infection and Immunity 78 2272-2282. (doi:10.1128/IAI.01374-09)

Zaharik ML, Nayar T, White R, Ma C, Vallance BA, Straka N, Jiang X, ReyLadino J, Shen C \& Brunham RC 2007 Genetic profiling of dendritic cells exposed to live- or ultraviolet-irradiated Chlamydia muridarum reveals marked differences in CXC chemokine profiles. Immunology $\mathbf{1 2 0}$ 160-172. (doi:10.1111/j.1365-2567.2006.02488.x)

Zuck M, Ellis T, Venida A \& Hybiske K 2017 Extrusions are phagocytosed and promote Chlamydia survival within macrophages. Cell Microbiology 19 e12683. (doi: 10.1111/cmi.12683)

Received 10 October 2016

First decision 24 November 2016

Revised manuscript received 1 July 2017

Accepted 11 July 2017 